\title{
ELEMENTS OF NARRATIVE AND FUNCTION OF NARRATOR IN JUN CHIU'S CROP CIRCLES
}

\author{
Dini Oktavia, Rahmadsyah Rangkuti, Muhammad Yusuf \\ Universitas Sumatera Utara, Medan, Indonesia \\ E-mail: dinnyivia19@gmail.com
}

Received: 11 August 2020

Accepted: 05 December 2020

\begin{abstract}
The purposes of this study are to find out the elements of narrative and the function of narrator in Jun Chiu's silent comic Crop Circles. This research applied qualitative design. The data of this study were in the form of 20 pictures taken from the silent comic. The data were collected through stages: finding out and determining, classifying and separating the pictures conveying illustration of a narrative. The analysis of the data was done qualitatively by using the theory of phase analysis by Miles, Huberman and Saldana covering condensation, display and verification. The research results show that the elements of narrative found in Jun Chiu's comic pictures Crop Circles narrative mood (transposed speech-indirect style); narrative instance (narrative voice: heterodiegetic narrator, time of narration: simultaneous narration; narrative perspective: external focalization), narrative levels (embedded narrative, metalepsis) and narrative time (order: analepsis, narrative speed: ellipsis, frequency of events: singulative narration). The narrator carried ideological function because the narrator illustrates the pictures to introduce public policy.
\end{abstract}

Keywords: narratology, silent comic, transposed speech, ideological function.

\section{Introduction}

Semiotics is the study of signs and it is one of applied linguistic branches. Signs take the form of words, images, sounds, odours, flavours, acts or objects but such things have no intrinsic meaning and become signs only when we invest them with meaning. Semiotics deals with meaning, symbol, or sign used as the message (Peirce, 1958).

Narrative semiotics is one part of semiotics. Narrative semiotics discusses about sign relationships contained in narrative and one of the studies in narrative semiotics is narratology or in other words narrative theory (Marsen et al., 2003).

This project is an attempt to analyse narrative elements found in silent comics of Jun Chiu's Crop Circles by using narrative theory proposed by Genette (1980). He notes that there are four categories of narrative elements narrative mood, narrative instance, narrative levels and narrative time. Narrative time is how the story is presented with respect to the narrative as a whole, with respect to the final result. Narrative time consists of three kinds: order, narrative speed and frequency of events.

\section{Literature Review}

Narrative theory, or internationally accepted term narratology, is the study of narrative as a genre. Its objective is to describe the constants, variables and combinations typical of 
Elements of Narrative and Function of Narrator on Jun Chiu's Crop Circles, Dini Oktavia, Rahmadsyah Rangkuti, Muhammad Yusuf

narrative and to clarify how these characteristics of narrative texts connect within the framework of theoretical models (typologies) (Fludernik, 2009: 8).

Narrative is a story which is linked to series of times. It deals with problematic events which lead to a crisis or turning point of some kind which in turn finds a resolution (Wellek \& Warren, 1989: 280).

Silent comics, also known as wordless comics, are comics without text in captions or word balloons. Silent comics are not strictly silent, because they often include sound effects in various forms such as pictographs in word balloons. One could say that silent comics are soundless in the same way that silent film is soundless, namely that while they do not include verbal dialogue, they show or imply sound in numerous ways because the worlds they represent are not silent (Postema, 2016:i).

\section{Elements of Narrative}

\section{Narrative Mood}

In narrative mood, there is element called distance. Distance is useful for readers in order to specify the degree of precision exactly and specifically in a narrative and the accuracy given by the information.

\section{Narrative Instance}

The narrative instance is known to be the connector between (1) narrative voice (the one who speaks?), (2) narrative time (when it happens) and (3) narrative perspective (by whom we are perceiving).

\section{Narrative Levels}

Variants of reading effects are seen from switching narrative levels, which are known traditionally as embedding. In the dominant plot, the writer or the author of the narrative is able to include other short attached narrative, told by other narrative perspectives. This is commonly a general technique which adds diversion to narrative actions and increases the amount complexity in narrative.

\section{4. $\quad$ Narrative Time}

Genette (1980) also thinks of questions about narrative time: how are stories presented in relation to the overall narrative, in relation to the last results? Once more, some methodological choices are suitable for authors. To reach the results expected, they are able to distinguish narrative sequences, narrative speed and frequency of events.

\section{Function of Narrator}

Genette (1980: 255-256) lists five functions of the narrator revealing the degree to which the narrator intervenes in his narrative, based on the desired degree of detachment or involvement:

1. The narrative function.

2. The directing function.

3. The communication function.

4. The testimonial function.

5. The ideological function. 


\section{Research Method}

This study is a qualitative design. It is reasonable because of the data in this study are qualitative data. According to Miles, Huberman and Saldana (2014:15), The data of this study are in the form of 20 pictures found in silent comic. The data source of this study is 20 pictures found in Jun Chiu's Crop Circles that was published on June 4, 2016 (oBORNo, 2016) and taken by running a Google search of various keywords related to Jun Chiu's Crop Circles.

These data collections from the pictures of Jun Chiu's Crop Circles were done by the following procedures:

1. Finding out and determining the pictures of Jun Chiu's Crop Circles.

2. Grouping the data related to the problem.

3. Classifying the components of narrative and functions of the narrator in the pictures of Jun Chiu's Crop Circles.

4. Separating the pictures of Jun Chiu's Crop Circles which included into the components of narrative and functions of the narrator.

The data condensation in this research is Selecting which determines dimensions which are more important and relationships which may be more meaningful focusing the data on Jun Chiu's Crop Circles comic as the object of the data. Abstacting the data and getting the data qualifies the theory proposed by Genette (1980). Simplifying and Transforming such as through rigorous selection, by summary or short description and transforming the data into a broader pattern are also done. The data display of this research is presented in the form of narration. Verification and Data Drawing is by reading and understanding the materials, analysing the pictures in the silent comic based on Genette theory, classifying the pictures into elements of narrative and function of narrator and making conclusion.

\section{Results and Discussion}

There are four elements of narrative in the slient comic of Jun Chiu's Crop Circle : Narrative Mood, Narrative Instance, Narrative Levels, Narrative Time.

\subsection{Elements of Narrative}

\section{Narrative Mood}

All the pictures in Jun Chiu's Crop Circles based on Narrative Mood analysis is Distance, that is Transposed Speech-Indirect Style because the narrator tells the story without using text or dialogues.

\section{Narrative Instance}

\section{Narrative Voice}

Narrative voice is the first element in narrative voice, which talks about who is speaking or who tells the story. The type of narrative voice found in Jun Chiu's Crop Circles is Heterodiegetic Narrator because the characters that appear vary and each character tells everything through their actions and the writer does not appear in the story.

\section{Time of Narration}


Elements of Narrative and Function of Narrator on Jun Chiu's Crop Circles, Dini Oktavia, Rahmadsyah Rangkuti, Muhammad Yusuf

Time of narration talks about when the story happens and it can be classified into four subsequent narrative (what happens in the past); prior narrative (what happens in the future); simultaneous narration (what happens at the present time); and interpolated narration (combination between simultaneous and subsequent narrative). The type of time of narration found in Jun Chiu's Crop Circles is simultaneous because the plot moves forwards.

\section{Narrative Perspective}

Narrative perspective tells about the point of view (focalization) and it can be divided into three kinds: zero focalization, internal focalization and external focalization. So, the kind of narrative perspective found in silent comic of Jun Chiu's Crop Circles is external focalization because the narrator does not tell everything about the story but let the characters show the story by their action.

\section{Narrative Levels}

Narrative levels are divided into two kinds: Embedded Narrative (focus on the levels of the story) and Metalepsis (focus on variations in narrative levels). Embedded Narrative consists of three levels: extradiegetic level, the intradiegetic level and metadiegetic level. The analysis of embedded narrative and metalepsis are presented below:

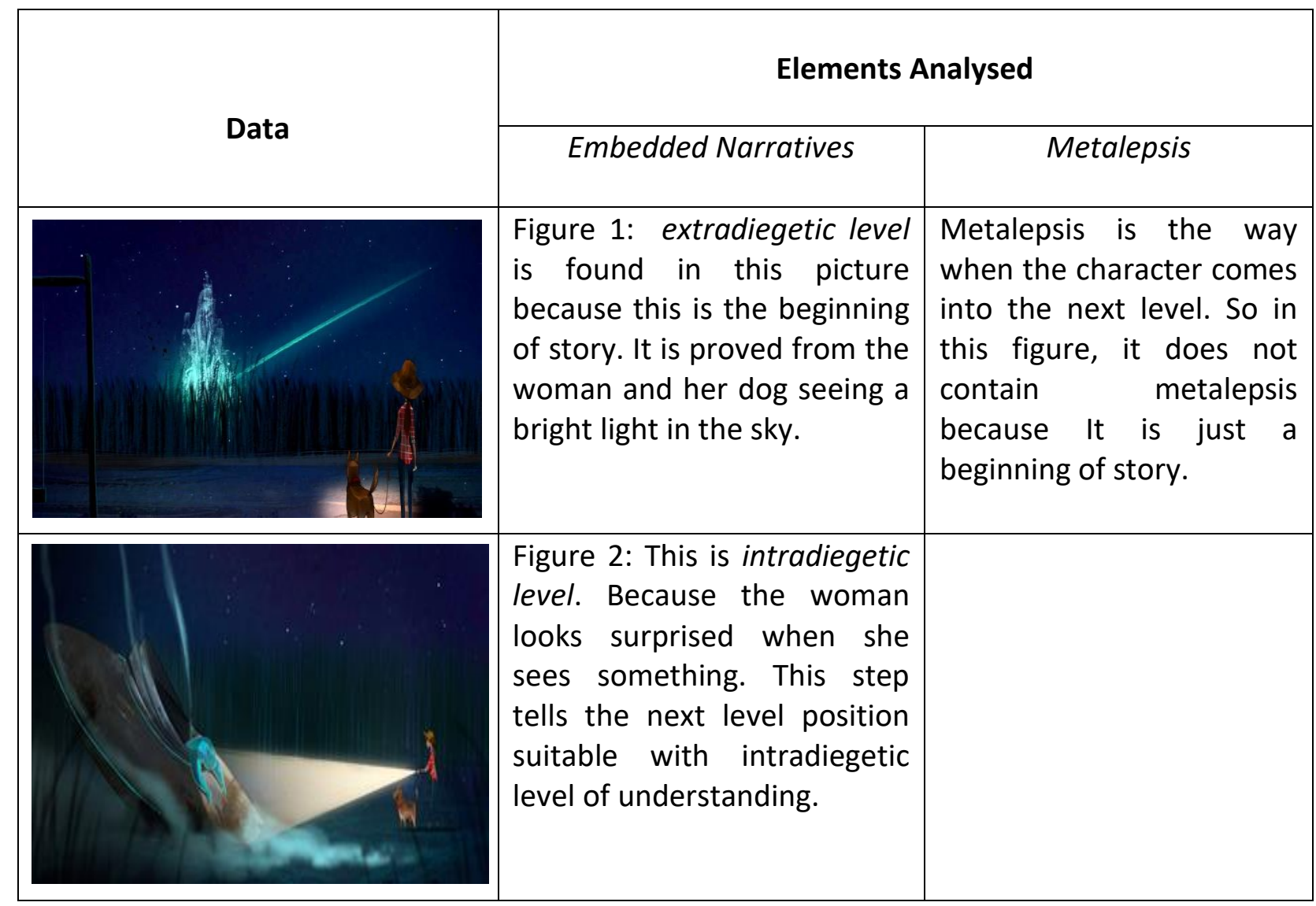




\begin{tabular}{|c|c|c|}
\hline 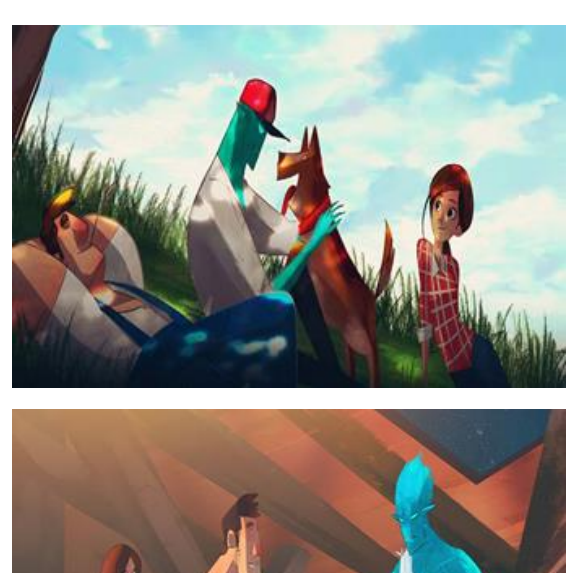 & $\begin{array}{l}\text { Figure } 3 \text { and } 4 \text { : This is } \\
\text { extradiegetic level. This } \\
\text { picture is not the beginning } \\
\text { of the story, it is seen from } \\
\text { the narrator showing the } \\
\text { characters. The reader can } \\
\text { see that the shadow in the } \\
\text { first picture that is not real } \\
\text { human, but Alien. They are } \\
\text { not afraid and they join the } \\
\text { Alien happily. }\end{array}$ & $\begin{array}{l}\text { The picture contains } \\
\text { metalepsis; the character } \\
\text { has faced the next level. }\end{array}$ \\
\hline & $\begin{array}{l}\text { Figure 9: This is intradiegetic } \\
\text { level. Because the picture } \\
\text { tells the next level of the } \\
\text { story in which the reader can } \\
\text { see the eyes and mouth of } \\
\text { the woman who looks very } \\
\text { surprised. Suddenly she saw } \\
\text { her dog being shot. }\end{array}$ & $\begin{array}{l}\text { This picture contains } \\
\text { metalepsis because this } \\
\text { picture moves into the } \\
\text { next level. }\end{array}$ \\
\hline Wha & $\begin{array}{l}\text { Figure } 14 \text { and } 20 \text { : This picture } \\
\text { is still in intradiegetic level } \\
\text { because this picture tells the } \\
\text { next level of the story which } \\
\text { the reader can see who could } \\
\text { save that the woman's dog. } \\
\text { Alien came and gave life to } \\
\text { the dog. }\end{array}$ & \\
\hline 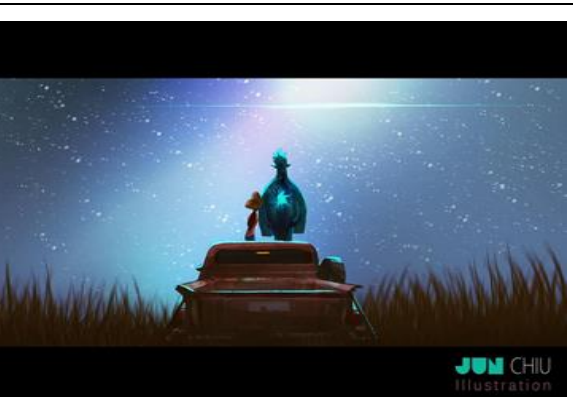 & $\begin{array}{l}\text { This picture contains } \\
\text { metadiegetic level because } \\
\text { this last event of this story } \\
\text { was told by the narrator, as } \\
\text { the reader can see that the } \\
\text { woman seems very happy to } \\
\text { live together with the dog. }\end{array}$ & \\
\hline
\end{tabular}

\section{Narrative Time}

Narrative time is how the story is presented with respect to the narrative as a whole, with respect to the final result. Narrative time consists of three kinds: order, narrative speed and frequency of events. 
Elements of Narrative and Function of Narrator on Jun Chiu's Crop Circles, Dini Oktavia, Rahmadsyah Rangkuti, Muhammad Yusuf

\section{Order}

Order is the relationship between the sequencing of events in the story and their arrangement in the narrative. Order consists of two kinds: analepsis and prolepsis. The kind of Order found in Jun Chiu's silent comic Crop Circles is analepsis because the narrator introduces the characters, shows the place and tells the events from the beginning of the story as illustrated in the following pictures:
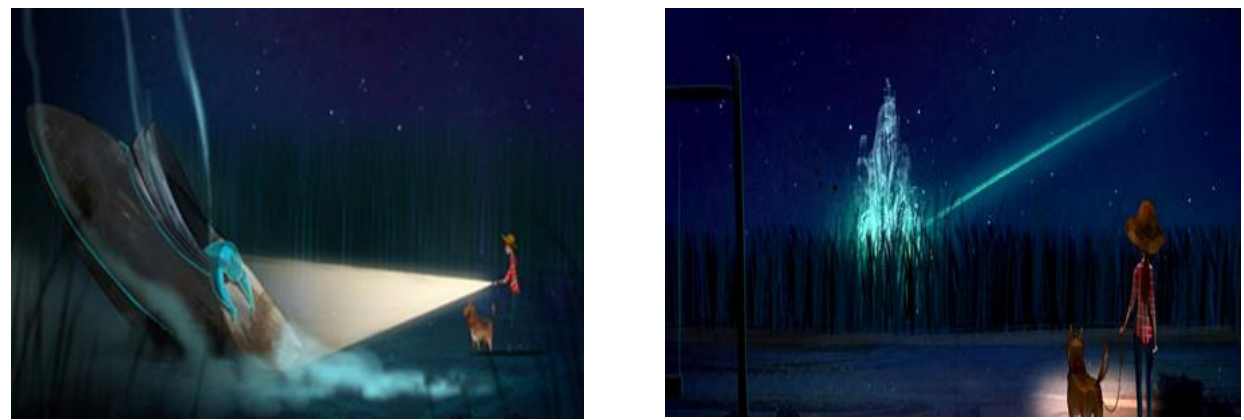

Through the picture above, the author presents three characters namely a woman, a dog and extraterrestrials namely alien. The author also displays the location of the meeting between the three of them. It can be said that the writer presents the story chronologically from the start.

\section{Narrative Speed}

Narrative speed is the duration of movement of interwoven events in a narrative. The ideal stories do have the same duration as the staged narrative. There are four lists of narrative movements: pause (there is space or room for narrative discourse), scene (there is narrative time according to story time), summary (there is summary of the narrative) and ellipsis (there is no explanation about story). The kind of narrative speed found in Jun Chiu's silent comic, Crop Circles is Ellipsis because the data of this research are from silent comic.

\section{Frequency of Events}

Narrative frequency can be a good relationship between the numbers of times when a moment happens. A system of relationships can be built between these capacities for repetition of two moments or events. There are four types of frequency relations: Singulative narrative (telling what happened once), Repeating narrative (telling more than once what happened once) and Iterative narrative (telling one time what happened several times). The type of frequency of events found is only Singulative Narration and this can be proved from the pictures below:
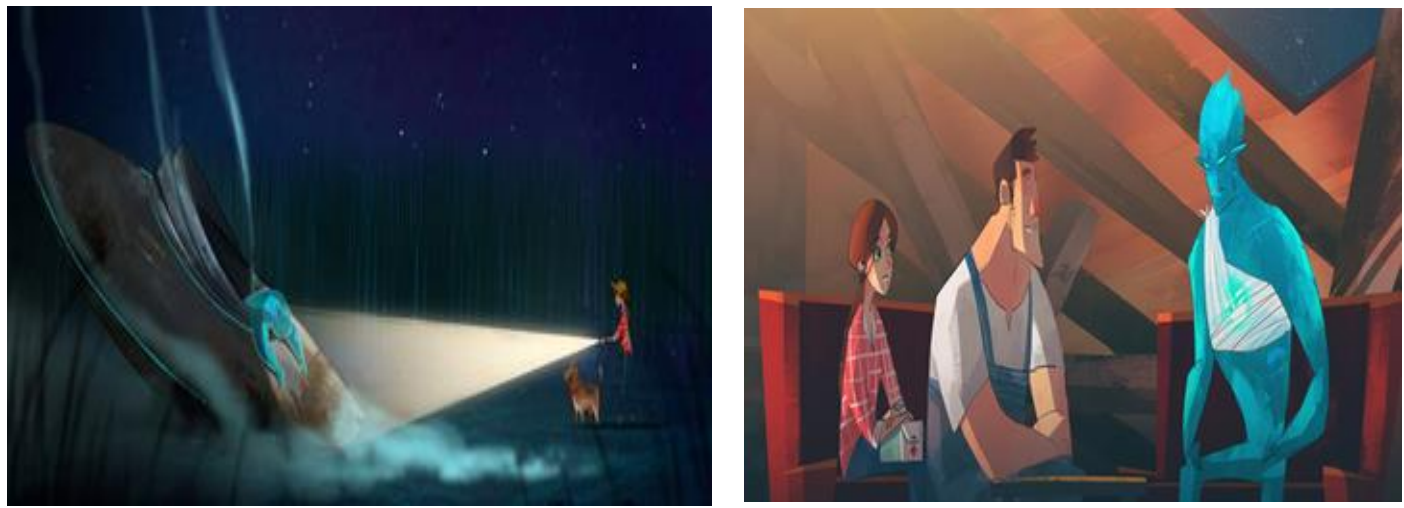
From the picture above, it can be seen that the Alien was found by the woman and he was injured. His action happens in one time and based on this reasons, this picture containing Singulative Narration was chosen.

\subsection{Function of Narrator}

The function of narrator in silent comic-Crop Circles is the ideological function because the narrator wants to introduce public policy. The narrator, Jun Chiu wants to convey education to the public that there are other creatures outside of humans that deserve to be respected. He argues that a loving relationship can be established between humans, animal and extraterrestrials. It is proved from how he weaves a love story between a girl and an alien who gets an obstacle from the security forces but this story takes place with a happy ending.

\section{Conclusion}

Based on the result and the discussion given above, it is concluded that elements of narrative found in Jun Chiu's Crop Circles are narrative mood (transposed speech-indirect style); narrative instance (narrative voice: heterodiegetic narrator, time of narration: simultaneous narration; narrative perspective: external focalization), narrative levels (embedded narrative, metalepsis) and narrative time (order: analepsis, narrative speed: ellipsis, frequency of events: singulative narration). The function of the narrator of Jun Chiu's Crop Circles is the ideological function as he wants to introduce public policy.

\section{References}

Fludernik, M. (2009). An Introduction to Narratology. New York: Routledge.

Genette, G. (1980). Narrative Discourse: An Essay in Method. Trans. Jane E. Lewin. Ithaca: Cornell University Press.

Marsen, S., Biddle, R., \& Noble, J. (2003). Use Case Analysis with Narrative Semiotics. In J. Ang, \& S-A. Knight (Eds.), Proceedings of the Australasian Conference on Information Systems (ACIS 2003) (pp. 1.1-1.8). Joondalup, W.A: We-B Centre. https://researchers.mq.edu.au/en/publications/use-case-analysis-with-narrativesemiotics.

Miles, M. B, Huberman, A. M. \& Saldana, J. (2014). Qualitative Data Analysis-A Sourcebook of New Methods, Beverly Hill: SAGE Publisher, Ltd.

Peirce, Charles Sanders. (1958). The Collected Papers of Charles Sanders Peirce, Vols. I-VI ed. Indiana: Indiana University Press.

Postema, Barbara. (2016). Silent Comics. https://www.routledgehandbooks.com.

Wellek, Rene dan Warren, Austin. (1989). Teori Kesusastraan (Terjemahan Melani Budiyanto). Jakarta: Gramedia. 